\title{
A Rare Case in Turkey: Cocaine-induced Multifocal Leukoencephalopathy
}

\author{
Türkiye’de Nadir Bir Olgu: Kokain İlişkili Multifokal Lökoensefalopati
}

\author{
(1) Esra Erdil, (1) Handenur Tunç, (1) Kadriye A ğan \\ Marmara University Faculty of Medicine, Department of Neurology, Istanbul, Turkey
}

\begin{abstract}
Use of cocaine can cause neorologic disorders such as hemorrhagic and ischemic cerebrovascular disease, seizure, neuropsychiatric complications, movement disorders, cerebral vasculitis, reversible cerebral vasoconstriction syndrome, and multifocal leukoencephalopathy. Among them, multifocal inflammatory leukoencephalopathy occurs rarely and is found to be related with a cocaine adulterant, levamisole. In this report, a case of cocaine/levamisole-related multifocal inflammatory leukoencephalopathy appearing with clinical features of catatonia is presented. A 34-year-old female patient was evaluated with symptoms of loss of contact and abnormal behaviour at the emergency department. She was living in Austria and had used cocaine three weeks before admission to hospital. A neurologic examination revealed increased speech latency, echolalia, and poor cooperation. Cranial magnetic resonance imaging showed bilateral fluid-attenuated inversion recovery and T2 hyperintense round-oval shaped lesions with patchy restricted diffusion and heterogenous contrast enhancement in subcortical periventricular white matter. Cranial imaging findings mimicked demyelinating diseases in this patient. Probable use of levamisole-adulterated cocaine, by enhancing immune response, caused levamisole-related multifocal leukoencephalopathy. The patient was started on pulse methylprednisolone treatment. At the request of the patient, on the sixth day of the treatment, she was transferred abroad and further follow-up could not be made. It is known that the use of levamisole, either for medical purpose or as an illegal substance, triggers multifocal leukoencephalopathy by means of complex immune mechanisms. The clinical presentation, radiologic impression, and histological findings of this condition are compatible with demyelinating diseases. Given the increased incidence use of cocaine with its most common adulterant levamisole, recognition and clinical management of its neurologic complications is crucial.
\end{abstract}

Keywords: Levamisole, cocaine, leukoencephalopathy, magnetic resonance

$\ddot{O} \mathbf{z}$

Kokain kullanımı hemorajik ve iskemik serebrovasküler hastalık, nöbet, nöropsikiyatrik komplikasyonlar, hareket bozuklukları, serebral vaskülit, reversibl serebral vazokonstrüksiyon sendromu, multifokal lökoensefalopati gibi nörolojik rahatsıllkklara yol açabilir. Bunlardan multifokal enflamatuvar lökoensefalopati nadir görülmektedir ve kokaine karıştırılan madde olan levamizol ile ilişkili bulunmuştur. Bu yazıda katatoni belirtileri ile başvuran kokain/levamizol ilişkili multifokal enflamatuvar lökoensefalopati olgusu sunulmaktadır. Otuz dört yaşında kadın hasta cevap vermede azalma ve normal dışı davranışlarının olması nedeni

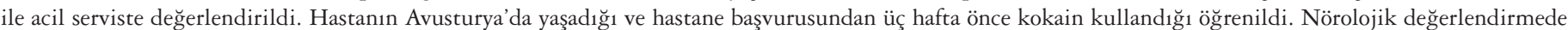
uzamış konuşma latansı, ekolali ve kooperasyon kısıtlılı̆̆ı saptandı. FLAIR ve T2 ağırlıklı kraniyal görüntülemede bilateral subkortikal periventriküler yapılarda hiperintens çok sayıda yuvarlak-oval şekilli, yer yer difüzyon kısıtlaması ve heterojen zayıf kontrast tutulumu gösteren lezyonlar izlendi. Kraniyal görüntüleme bulguları demiyelinizan hastalık düşündüren bu olguda, olası levamizol ilave edilmiş kokain kullanım öyküsü olduğundan levamizol ilişkili multifokal lökoensefalopati tanısı ön planda düşünüldü. Hastaya pulse metilprednizolon tedavisi başlandı. Tedavinin altıncı gününde hasta, yurtdışına nakil yaptırma isteği ile hastaneden ayrıldığından ileri klinik takip yapılamadı. Levamizolün medikal ya da illegal madde olarak kullanımı sonrası kompleks immün mekanizmalar üzerinden multifokal lökoensefalopatiyi tetikleyebildiği bilinmektedir. Klinik prezentasyon, radyolojik görüntüleme ve histopatolojik bulguları ile demyelinizan hastalıklara benzerdir. Kokain kullanımının gittikçe arttığı düşünüldüğünde, en sık kokaine karıştırılan madde olan levamizole bağlı bu nörolojik tablonun tanınması ve klinik yönetimi önemlidir.

Anahtar Kelimeler: Levamizol, kokain, lökoensefalopati, manyetik rezonans

Address for Correspondence/Yazışma Adresi: Esra Erdil MD, Marmara University Faculty of Medicine, Department of Neurology, Istanbul, Turkey Phone: +90 5325433089 E-posta: erdilesra@gmail.com ORCID: orcid.org/0000-0003-4486-1710

Received/Geliş Tarihi: 26.10.2019 Accepted/Kabul Tarihi: 01.06.2020

${ }^{\circ}$ Copyright 2020 by Turkish Neurological Society

Turkish Journal of Neurology published by Galenos Publishing House. 


\section{Introduction}

Cocaine use may lead to complications such as hemorrhagic and ischemic cerebrovascular disease, seizures, neuropsychiatric complications, movement disorders, cerebral vasculitis, cerebral vasoconstriction syndrome, and multifocal leukoencephalopathy. The neurologic adverse effects of cocaine use are considered to be caused by mechanisms such as primary a neurotoxic effect through toxic encephalopathy, a secondary effect by disrupting cerebral blood flow, and a tertiary effect by causing cardiopulmonary collapse and creating hypoxia (1). Among the neurologic complications that develop due to cocaine use, multifocal inflammatory leukoencephalopathy is rarely seen and has been found to be associated with levamisole, the substance mixed with cocaine (2).

Levamisole has been shown to be effective in many inflammatory and oncologic processes such as rheumatoid arthritis, aphthous ulcer, and melanoma (3). This substance, which was approved as an adjuvant agent in the use of colorectal cancer, was later withdrawn from the market due to its adverse effects. A more current use is its addition to illegal recreational substances in order to increase the effect and amount (4).

Levamisole was observed to be the most common additive substance in cocaine samples, with varying rates of $70 \%$ in the United States, $31.8 \%$ in Italy, and $55.6 \%$ in Brazil $(4,5)$. Another indicator of the frequency of using levamisole with cocaine is the positive detection of levamisole in $68 \%$ of individuals with cocaine in their urine (6).

Levimazole, when used with cocaine, is thought to strengthen cocaine as a pleasurable substance. The effect of levamisole on many neurostansmitter levels in the central nervous system proves this. It has been found that endogenous morphine and codeine levels increased in the brain and peripheral organs after levamisole intake in rats. Also, it has been shown to change norepinephrine, dopamine and serotonin metabolism, and increase the active release of dopamine in some regions of the brain (7). It has also been shown to activate human nicotinic receptors and inhibit monoamine oxidase $(8,9)$.

The serious adverse effects of levamisole include necrotizing vasculopathy, leukopenia, agranulocytosis, pulmonary hemorrhage, arthritis, and embolism. Another important adverse effect is multifocal inflammatory leukoencephalopathy. Multifocal inflammatory leukoencephalopathy, which was also defined as monophasic cerebral demyelinating disease, was first described in three patients with colorectal cancer in 1992 (10). Later, this adverse effect of levamisole was published as case reports after its use as a medical or cocaine additive.

When the postmortem brain tissue of 10 patients that resulted in cocaine-related death was evaluated, it was observed that the amount of hydroxyzine and levamisole was moderate to high in some brains. It was thought that this situation increased the toxicity of the cocaine and contributed to death (11). There are currently some predictions as to how levamisole might trigger this inflammatory process. One of the most important immune systemrelated effects is to activate monocyte chemotaxis; apart from this, it is thought to trigger macrophage and $\mathrm{T}$ lymphocyte activation, $\mathrm{T}$ cell maturation, and the production of some cytokines (IL-1) via Th1. It has also been reported that it causes hypersensitivity reactions and antigen-antibody complex formation $(12,13)$.

In this article, we present a patient with confusion who used cocaine three weeks before her presentation and was followed up with the diagnosis of multifocal inflammatory leukoencephalopathy associated with cocaine/additive substance.

\section{Case Report}

A 34-year-old female patient without a history of illness was brought to the emergency department with a 3-day history of increasing confusion. It was observed by her mother that she had difficulty finding words in the last three days, her speech decreased, she repeated what was said from time to time, and could not perform simple daily life activities such as dressing. It was learned from her husband that she used 15 grams of cocaine by inhalation three weeks ago while she was abroad.

In the neurologic examination, the patient was disoriented, the content of her speech was poor and repetitive. In fluid-attenuated inversion recovery and T2-weighted cranial images, hyperintense, multiple and round-oval-shaped lesions with diffusion restriction and heterogeneous weak contrast uptake were observed in bilateral subcortical periventricular structures (Figures 1, 2, 3). When the imaging findings were evaluated, demyelinating diseases, especially acute disseminated encephalomyelitis (ADEM), and cerebral abscess were included in the differential diagnosis. No cocaine metabolite was not detected in urine screening, which could

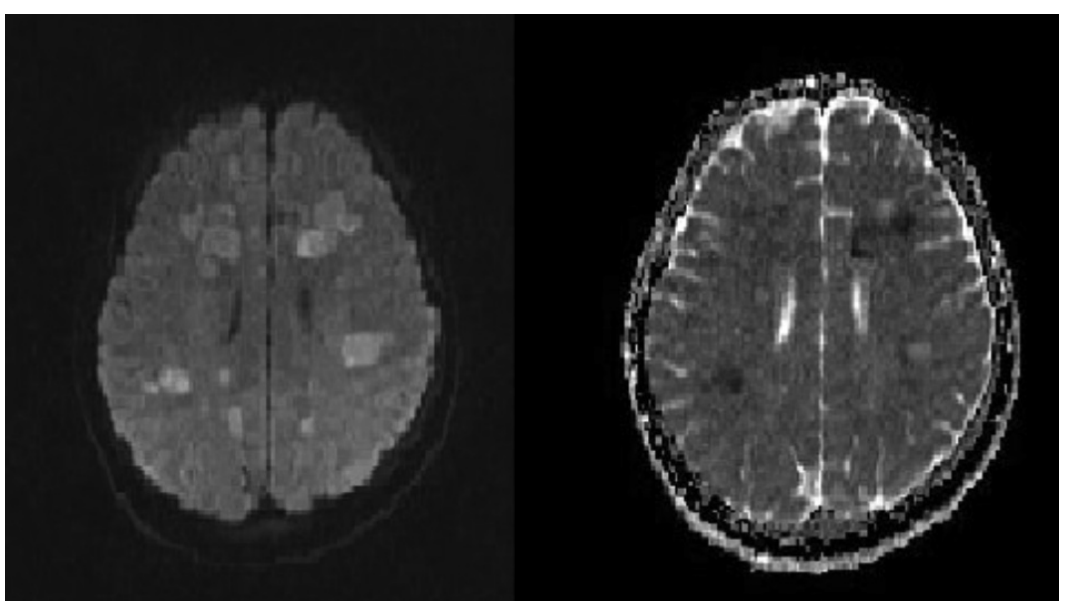

Figure 1. Diffusion-weighted images 


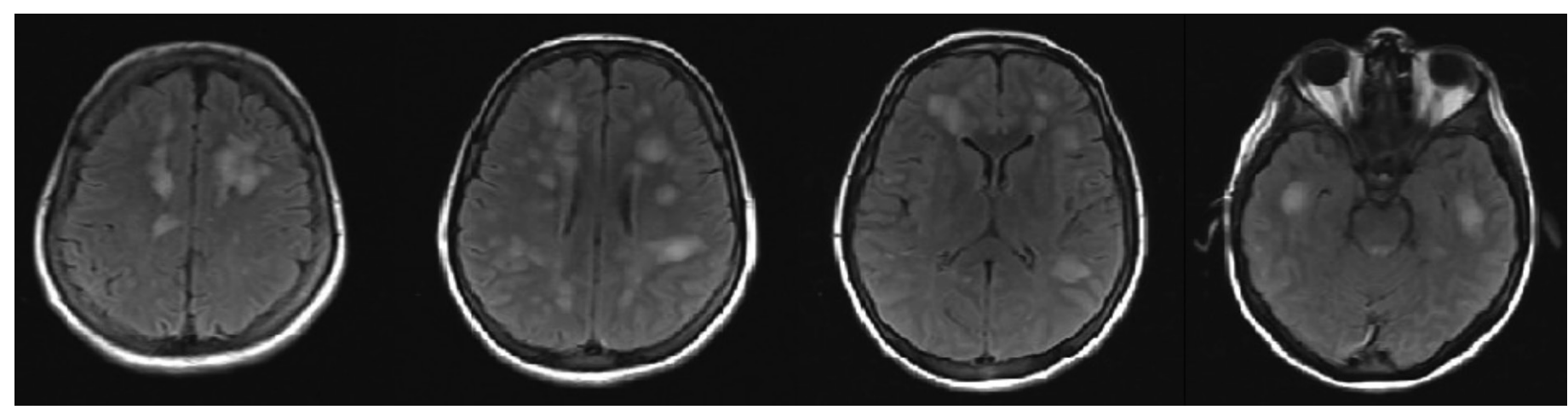

Figure 2. FLAIR aksiyal görüntülemeler

FLAIR: Fluid-attenuated inversion recovery

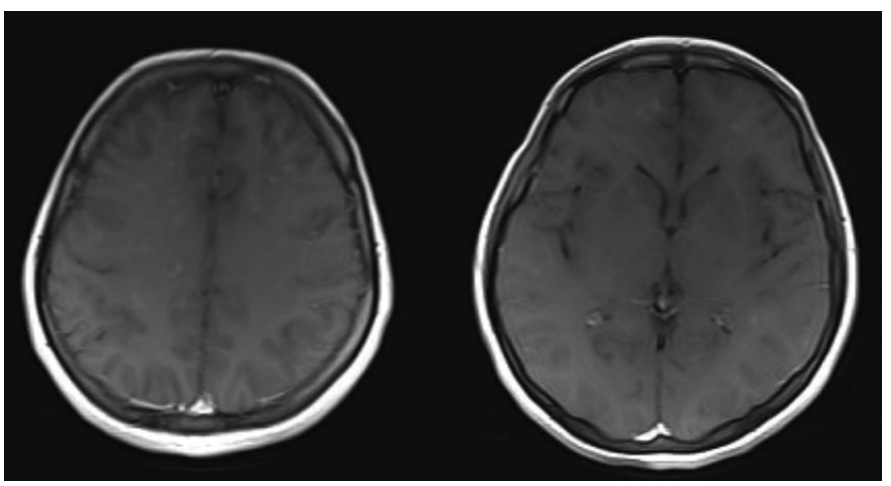

Figure 3. Contrast-enhanced T1-weighted axial images

be checked four weeks after the active use history. Cerebrospinal fluid (CSF) examination findings were as follows; protein: 61.8 $\mathrm{mg} / \mathrm{dl}$ (normal: $15-45 \mathrm{mg} / \mathrm{dl}$ ), glucose: $59 \mathrm{mg} / \mathrm{dl}$, cell count under microscope: $20 / \mathrm{mm}^{3}$ (75\% lymphocytes). Cryptococcal antigen, cytomegalovirus, herpes simplex virus (HSV), varicella-zoster virus, and enterovirus polymerase chain reaction tests in the CSF were negative. The patient was started on $1 \mathrm{~g} /$ day intravenous methylprednisolone treatment. On the $6^{\text {th }}$ day of the pulse methylprednisolone treatment, the patient and her relatives left the treatment and wanted to transfer the patient abroad.

\section{Discussion}

Levamisole-associated multifocal inflammatory leukoencephalopathy is accepted as an inflammatory process caused by the effects of levamisole on the immune system. This process shows similarities with clinical presentation and neuroradiologic imaging findings with other demyelinating diseases, especially ADEM.

Our patient had used cocaine three weeks ago for the first time in her life and presented with a sudden deterioration in cognitive functions. The absence of cocaine metabolite in the samples of our case was attributed to the fact that time had passed since its use.

In levamisole-associated multifocal leukoencephalopathy, symptoms typically begin subacute days to weeks after levamisole exposure. The main symptoms are motor weakness, hypertonia, aphasia, apathy, and memory and calculation disorders (14). Within a few days, symptoms peak and then progress to relatively stable (13); however, it may be fatal in some patients.
In CSF findings, as in our patient, mild lymphocytic pleocytosis, a normal glucose level, and normal to slightly increased protein levels are observed. The presence of oligoclonal bands and increased immunoglobulin $\mathrm{G}$ index are relatively rare (14).

Neuroradiologic findings are similar to demyelinating diseases at first glance, and in cases of sudden deterioration of consciousness, if a history of substance use cannot be taken recently, they may suggest diseases such as ADEM or Balo's concentric sclerosis (15). When biopsies of levamisole-associated brain lesions were examined histopathologically, active demyelination with loss of myelin and accumulation of perivascular lymphocytes was observed $(10,14)$.

Although the presence of levamisole was not proven in our patient, the diagnosis of levamisole-associated multifocal leukoencephalopathy was accepted as a highly probable prediagnosis. Clinically and radiologically, this patient was similar to the patients described in the literature. It is necessary to recognize neurologic conditions that can be caused by levamisole, which is increasingly used as an additive.

\section{Ethics}

Informed Consent: Written consent was obtained from the patient's parent.

Peer-review: Externally and internally peer-reviewed

\section{Authorship Contributions}

Surgical and Medical Practices: E.E., H.T., K.A., Concept: E.E., K.A., Design: E.E., Data Collection or Processing: E.E., Analysis or Interpretation: E.E., K.A., Literature Search: E.E., Writing: E.E.

Conflict of Interest: No conflict of interest was declared by the authors.

Financial Disclosure: The authors declared that this study received no financial support.

\section{References}

1. Kondziella D, Danielsen ER, Arlien-Soeborg P. Fatal encephalopathy after an isolated overdose of cocaine. J Neurol Neurosurg Psychiatry 2007;78:437438.

2. Larocque A, Hoffman RS. Levamisole in cocaine: unexpected news from an old acquaintance. Clin Toxicol (Phila) 2012;50:231-241.

3. Amery WKP, Bruynseels JP. Levamisole, the story and the lessons. Int J Immunopharmacol 1992;14:481-486.

4. Martello S, Pieri M, Ialongo C, et al. Levamisole in illicit trafficking cocaine seized: a one-year study. J Psychoactive Drugs 2017;49:408-412. 
5. Lapachinske SF, Okai GG, Santos A, Bairros AV, Yonamine M. Analysis of cocaine and its adulterants in drugs for international trafficking seized by the Brazilian Federal Police. Forensic Sci Int 2015;247:48-53.

6. Buchanan JA, Heard K, Burbach C, Wilson ML, Dart R. Prevalence of levamisole in urine toxicology screens positive for cocaine in an inner-city hospital. JAMA 2011;305:1657-1658.

7. Spector S, Munjal I, Schmidt DE. Effects of the immunostimulant, levamisole, on opiate withdrawal and levels of endogenous opiate alkaloids and monoamine neurotransmitters in rat brain. Neuropsychopharmacology 1998;19:417-427.

8. Hernando G, Berge I, Rayes D, Bouzat C. Contribution of subunits to caenorhabditis elegans levamisole-sensitive nicotinic receptor function. Mol Pharmacol 2012;82:550-560.

9. Agarwal A, Shukla OP, Ghatak S, Tekwani BL. Biogenic amines, metabolites and monoamine oxidase in the filarial worm setaria cervi. Int J Parasitol 1990;20:873-881.

10. Hook CC, Kimmel DW, Kvols LK, et al. Multifocal inflammatory leukoencephalopathy with 5-fluorouracil and levamisole. Ann Neurol 1992;31:262-267.
11. Knuth M, Temme O, Daldrup T, Pawlik E. Analysis of cocaine adulterants in human brain in cases of drug-related death. Forensic Sci Int 2018;285:8692.

12. Scheinfeld N, Rosenberg JD, Weinberg JM. Levamisole in dermatology: a review. Am J Clin Dermatol 2004;5:97-104.

13. Wu VC, Huang JW, Lien HC, et al. Levamisole-induced multifocal inflammatory leukoencephalopathy: clinical characteristics, outcome, and impact of treatment in 31 patients. Medicine (Baltimore) 2006;85:203-213.

14. Xu N, Zhou W, Li S, et al. Clinical and MRI characteristics of levamisoleinduced leukoencephalopathy in 16 patients. J Neuroimaging 2009;19:326331.

15. Sagduyu Kocaman A, Yalınay Dikmen P, Karaarslan E. Cocaine-induced multifocal leukoencephalopathy mimicking Balo's concentric sclerosis: a 2-year follow-up with serial imaging of a single patient. Mult Scler Relat Disord 2018;19:96-98. 